\section{Anastasia Vorobyova, Volodymyr Polyovyk, Iryna Koretska}

UDC 641.85:641.56

DOI: $10.15587 / 2706-5448.2021 .237260$

Article type «Reports on Research Projects»

\title{
DEVELOPMENT OF THE DESSERTS BASED ON NON-TRADITIONAL VEGETABLE RAW MATERIALS
}

Nowadays, the problem of healthy eating is acute. Most consumers prefer organic foods, dishes based on natural vegetables and fruits, and healthy nutrition. Thus, reducing calories content and increasing the nutritional value of sweet dishes is a promising area for the research. Therefore, the object of this study is the technology of whipped sweet «sambuk»-type dishes. To create the new desserts, non-traditional vegetable raw materials, namely physalis puree and banana puree, were chosen. Physico-chemical, mathematical, and dessert quality analysis methods were used in the study.

One of the most problematic tasks in the technology of whipped desserts is the stabilization of the foam structure. Therefore, the inclusion of physalis puree and banana puree in the recipe affects not only the organoleptic properties, but also improves the physical and chemical parameters of the dish. In particular, the aggregate stability coefficient of the foam increases to 4.33 in the samples with banana puree and to 3.48 in the samples with physalis puree, which is 2 and 1.66 times higher than the same indicator for control sample. The specific volume also has a noticeable improvement (it is 1.5 times higher in samples with physalis puree and 1.16 times higher in samples with banana puree comparing to control). During the study the effect of selected raw materials on the dry matter content in new desserts was determined (it ranges from $36.5 \%$ to $41.35 \%$ in samples with physalis puree and from $23.2 \%$ to $27.8 \%$ in the case of adding banana puree). The acidity of the model samples ranges from 4.8 to $4.61 \mathrm{pH}$ in desserts with physalis puree, and from 5.53 to $5.41 \mathrm{pH}$ in desserts with banana puree. Based on the expert assessment, the value of the sample quality criteria was determined. Conclusions are made on the expediency of non-traditional raw materials using in the preparation of whipped desserts.

Keywords: caloric content and benefits of sweet dishes, whipped dessert technology, physalis puree, banana puree.

Vorobyova, A., Polyovyk, V., Koretska, I. (2021). Development of the desserts based on non-traditional vegetable raw materials. Technology Audit and Production Reserves, 4 (3 (60)), 32-36. doi: http://doi.org/10.15587/2706-5448.2021.237260

\section{Introduction}

When choosing an exquisite dish, the chemical composition, the content of nutrients, vitamins, macro and micro-nutrients are extremely important. Over the years, consumers have developed a stereotype that if a dish is sweet and tasty, it is high in calories and not healthy, and the composition of desserts is associated with a high content of sugars, fats, carbohydrates, which are not contained in balanced quantities.

Analysis of recent studies and publications has shown that the basis of the calorie content of desserts is high in sugar [1, 2]. Typically, this component is used as a structurant and is added to the dish in order to provide high organoleptic characteristics and give the product a sweet taste. Only after bringing these indicators to a high level is attention paid to the calorie content and benefits of the resulting dish.

Sugar is a very energetically valuable product, but its excessive use entails a number of diseases that are difficult or not cured at all. In the first place among diseases is hyperglycemia - excess blood glucose negatively affects the functioning of the pancreas. Subsequently, excessive consumption of sugar can lead to an incurable disease - diabetes. In addition, $100 \mathrm{~g}$ of sugar marks $398 \mathrm{kcal}$ in themselves, which means that with a small expenditure of physical energy, part of this product will be converted into fat and stored in the body. This phenomenon can lead to rapid obesity, coronary heart disease and atherosclerosis [3, 4].

But the above does not mean at all that it is necessary to give up the use of desserts altogether in order to be healthy. It is necessary to create dishes that are both tasty and healthy at the same time. That is why desserts and sweet dishes are a promising direction in the development of special-purpose health food for restaurant establishments. One of the problematic areas in the technology of baked desserts is the choice of a new ingredient that would provide the necessary organoleptic and technological characteristics of the dish.

Considering the above, let's believe that the topic of improving the technology of sweet dishes and desserts is relevant. Thus, the object of the study is the technology of sambuk-type beef sweet dishes. And the purpose of 
the work is to develop apple sambuk technology using physalis puree and banana puree.

An urgent further development in the chosen direction is a comprehensive study of physicochemical and technological parameters to predict the effect of selected additives on the structure of sambuck dessert.

\section{Methods of research}

The research used the following scientific methods:

- method of analysis - when determining organoleptic indicators;

- physicochemical methods - when determining the specific volume, active acidity, redox potential, aggregated stability, kinetics of foam formation, dry matter content of the test samples;

- mathematical methods, performed both according to standard and original methods, using modern instruments and means of processing the results obtained.

Sampling was carried out in accordance with the requirements of DSTU 4939:2008, preparation of samples for laboratory analyzes - in accordance with DSTU 4941:2008.

In the study of physical and chemical indicators, the following was determined:

- content of mass fraction of dry substances in raw materials - according to DSTU ISO 751-2004;

- active acidity (pH) - according to GOST 1132:2005;

- redox potential and reduction energy;

- specific volume [5];

- foaming ability and foam stability [6].

The mass fraction of dry substances was determined by the accelerated method of drying in a drying oven.

A sample of sambuk in the amount of $5 \mathrm{~g}$ with an accuracy of $0.01 \mathrm{~g}$ was placed in weighing bottles filled with sand, everything was thoroughly mixed. Drying was carried out in a drying oven for $45 \mathrm{~min}$ at a temperature of $130{ }^{\circ} \mathrm{C}$. After that, the weighing bottles with the dried sample were cooled in a desiccator and weighed on an analytical balance.

Moisture content $M(\%)$ was calculated by the formula:

$$
M=\frac{m_{1}-m_{2}}{m_{2}-m} \cdot 100 \%,
$$

where $m_{2}$ - weight of the weighing bottle after drying, g; $m_{1}$ - weight of weighing bottle before drying, g; $m$ - mass of the weighing bottle.

The mass fraction of dry matter $X(\%)$ was calculated by the formula:

$$
X=100-M,
$$

where $M$ - humidity, \%.

One of the most significant indicators of the quality of desserts is the specific volume of products.

Specific volume is the volume of a unit mass of a substance, the reciprocal of density. Specific volume $v\left(\mathrm{~cm}^{3} / \mathrm{g}\right)$ was determined by the formula:

$$
v=\frac{V}{m}
$$

where $V$ - volume of the product; $m$ - mass of the product [5].

Foaming ability was determined by the Lurie method. For this, a measuring cylinder was used to measure
$20-50 \mathrm{~cm}^{3}$ of the test solution (depending on the predicted foaming ability) into a $500 \mathrm{~cm}^{3}$ beaker and knocked down with a mixer at a speed of 1500-2000 rpm until a certain required volume of foam is reached. The value of foaming ability (FA) in \% was calculated by the formula:

$$
F A=\frac{V f}{V s} \cdot 100 \%
$$

where Vf - foam volume, $\mathrm{cm}^{3}$; Vs - the volume of the solution before whipping, $\mathrm{cm}^{3}$.

The arithmetic mean of three determinations was taken as the final result, the discrepancy between which should not exceed $2 \%$.

Foam stability. To determine the stability of the foam, the height of the obtained knocked-down foam was measured, leaving it for 60 minutes and fixing the foam height after proofing. The calculation of foam stability (FS) in \% was carried out according to the formula:

$$
F S=\left(H_{f} / H_{f 60}\right) \cdot 100 \%,
$$

where Hf - initial foam height, cm; Hf60 - foam height after proofing for 60 minutes.

The arithmetic mean of three determinations was taken as the final result, the discrepancy between which should not exceed $2 \%$.

The organoleptic method is based on the use of information obtained as a result of the analysis of sensations perceived by the senses - sight, smell, hearing, touch and taste. In this case, the human sense organs perform the role of receivers and transducers of certain information.

To carry out an objective organoleptic assessment of the indicators - appearance, taste, color, texture, smell, a point was given.

Organoleptic assessment was given on a 10-point scale by ten experts. All indicators of product quality (appearance, taste, color, consistency, smell) are evaluated on a ten-point system: 10 - «excellent»; 8 - «good»; 6 - «satisfactory»; 4 - «unsatisfactory». The overall score is displayed as the arithmetic mean with an accuracy of one decimal place.

For each group of indicators, points are given according to their characteristics.

The organoleptic method is always of great importance. sing sophisticated laboratory research methods, it is impossible to determine very small amounts of various chemical substances of products, which, in combination, create a complex and characteristic taste, aroma, and smell. Only the organoleptic method allows to give an overall assessment of the consistency of the product.

Evaluation of expert opinions was carried out according to the method of determining the average value of the sum of all evaluations [7,8].

A ranking method was used to determine the weighting factors for each quality indicator. It lies in the fact that the least significant indicator is assigned a rank of 1 , and the most important - 10. This number of experts ensures sufficient accuracy of estimates.

\section{Research results and discussion}

To improve the technology of baked sweet dishes and expand the assortment of the group of desserts, it is necessary to add components to the product that will not 
only affect the calorie content and appearance of the dish. They should also increase the nutritional value of the dish and have a positive effect on the physicochemical indicators. A literature search and analysis of the patent base showed that raw materials such as physalis and banana were not previously used in the technology of baked desserts, therefore it is a promising area of research.

Analysis of the chemical composition of selected fruits is distinguished by a bright content of vitamins and microelements. This will have a positive effect on the nutritional value of the dish, and the high content of starch in banana and pectin in physalis will help stabilize the frothy structure of the baked desserts [9-11].

When conducting experiments for control, recipe No. 904 «Apple Sambuk» was chosen. When performing the experiment, model samples of sambuk were prepared (Table 1) with different concentrations of physalis and banana puree, and sugar was replaced with glucose-fructose syrup (DE-42).

Table 1

Model samples of sambuk

\begin{tabular}{|c|c|c|}
\hline Sample & $\begin{array}{c}\text { Fruit puree } \\
\text { content }\end{array}$ & Designation \\
\hline \multicolumn{2}{|l|}{ "Apple Sambuk» (control sample) } & M5-1 \\
\hline - with the introduction of physalis puree & $19.5 \%$ & M5-2 \\
\hline - with the introduction of physalis puree & $38.5 \%$ & M5-3 \\
\hline - with the introduction of physalis puree & $57.7 \%$ & MS-4 \\
\hline - with the introduction of mashed banana & $10 \%$ & MS-5 \\
\hline - with the introduction of mashed banana & $25 \%$ & M5-6 \\
\hline - with the introduction of mashed banana & $35 \%$ & MS-7 \\
\hline
\end{tabular}

Previous studies of the organoleptic parameters and taste properties of the selected raw materials showed the range of variation in the concentration of banana puree $10-35 \%$ and physalis puree $19.5-57.7 \%$, and this explains the fruit-component composition in model samples.

Sambuk is a dessert with a foamy structure, therefore, one of its most important physicochemical quality indicators is the foaming ability and the dynamics of foam formation [12]. The results of the experiments are presented in Fig. 1.

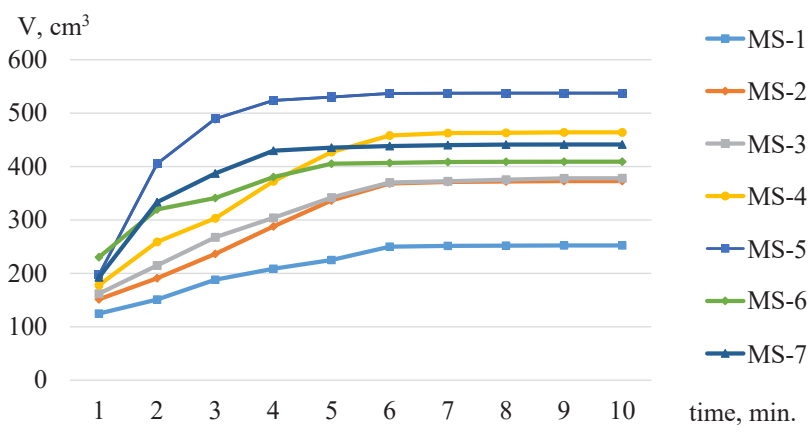

Fig. 1. Dynamics of changes in the volume of foam in the test samples

Analyzing the results of determining the kinetics of foaming of the prototypes, it can be concluded that the addition of physalis puree and banana puree improve this indicator relative to the control sample MS-1. In samples with banana puree (MS-5), the foaming ability increases up to 2 times, with physalis puree (MS-4) up to 1.5 times.

The study of the dynamics of foam formation when making fruit puree also changes (Fig. 2). For example, samples with physalis puree have a low but stable rate of foam forma- tion, and the use of banana puree accelerates this process. This is due to the high starch content of the banana puree, which works with the protein to form a fluffy, stable foam.

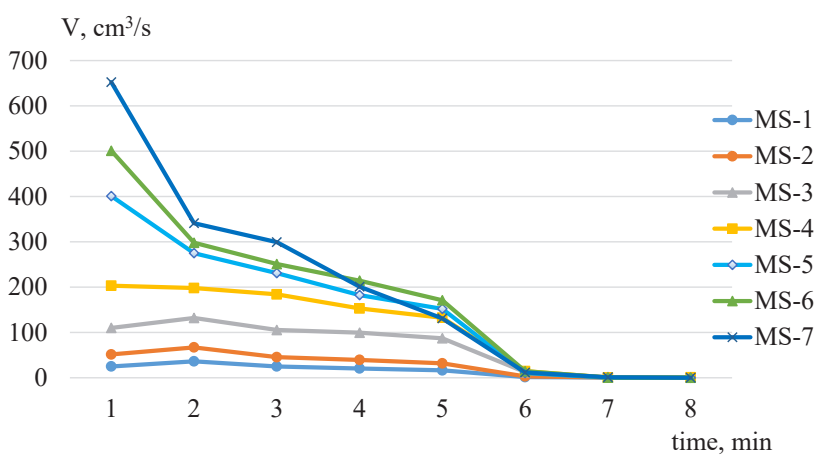

Fig. 2. Kinetics of the foam formation rate of the test samples

In dispersed systems characterized by better stability, the surface tension decreases, which means that the free surface energy, the Gibbs energy, decreases.

The change in the properties of the foam is associated with the high hydrophilicity of starch and pectin, which, with an increase in the viscosity of the dispersion medium to certain limits, improve its stability. High-viscosity adsorption layers with a gel-like structure are capable of forming in pencil cases. These layers, on the one hand, slow down the flow of liquid in the film, and on the other hand, they provide the foam film with high structural viscosity and mechanical strength [12].

To ensure the dessert of high quality, the determination of the coefficient of aggregate stability of foam (Fig. 3) will allow predicting the duration of the dish realization [13].

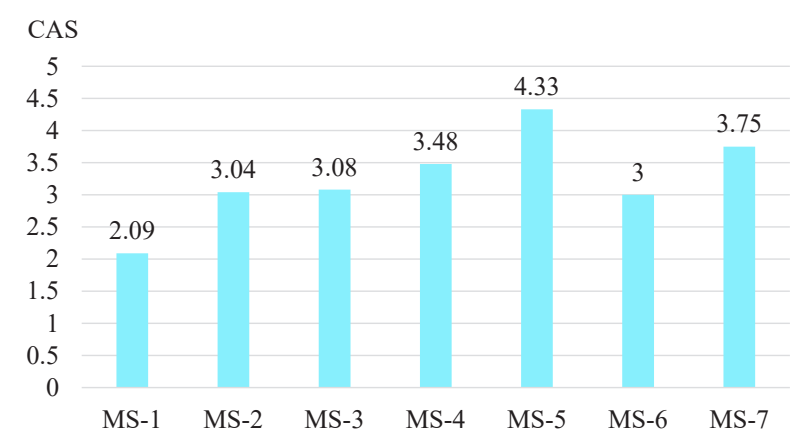

Fig. 3. Coefficient of aggregate stability of the foam of the test samples

Studies have shown that the MS-5 sample possesses the best aggregate stability, the stability coefficient of which is 2 times higher than the control at a banana puree concentration of $10 \%$. In the case of giving physalis puree, this indicator exceeds the control by 1.45 times at a puree concentration of $19.5 \%$ and 1.66 times at a puree concentration of $57.7 \%$. The lowest stabilizing properties were exhibited by sample MS-6 with a concentration of banana puree of $25 \%$, exceeding the control by 1.43 times.

The mass fraction of dry substances is the most important technological indicator that affects the determination of the quality of raw materials, semi-finished products and finished products. And the acidity of products is a standardized indicator that determines the taste of the product and determines the freshness and good quality of the dish. The content of dry substances in the test samples is shown in Fig. 4. 


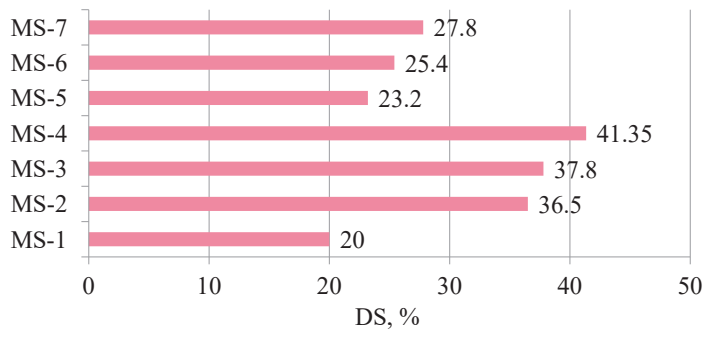

Fig. 4. Investigation of the content of dry substances in the test samples

As it is possible to see, when the selected products are added to the composition of the sambuk model samples, the dry matter content only increases. This is due to the rather high content of pectin substances in selected products.

One of the most significant indicators of the quality of desserts is the specific volume of products. The results of determining the specific volume of the prototypes are shown in Fig. 5.

As it is possible to see, a change in the percentage of physalis puree to applesauce significantly changes the specific volume of model samples.

An equally important indicator is the value of the active acidity of ready meals, which is shown in Fig. 6 .

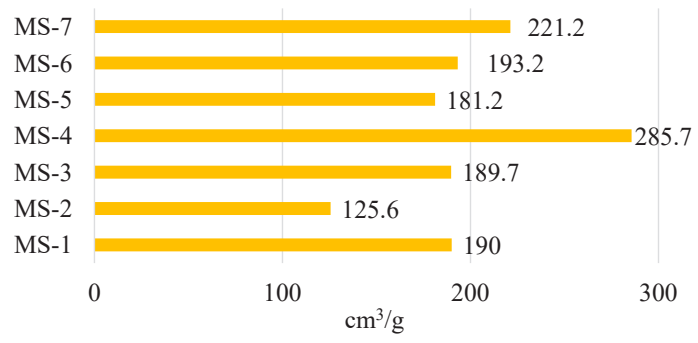

Fig. 5. Determination of the specific volume of the test samples

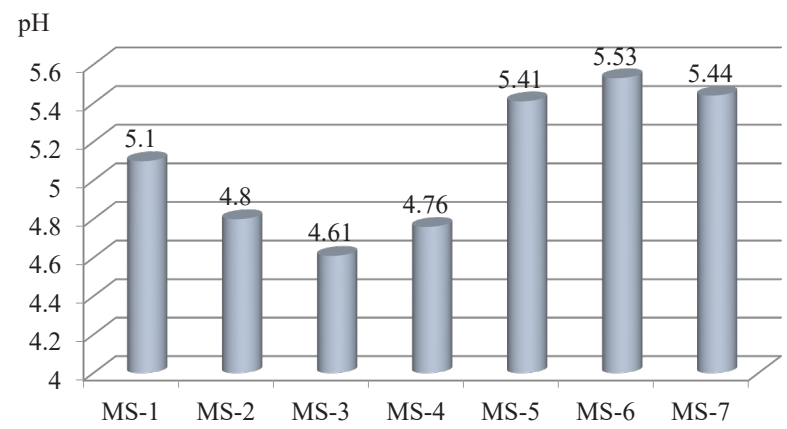

Fig. 6. Determination of the active acidity of the test samples

From the results obtained, it can be concluded that active acidity directly depends on the content of organic acids in the feedstock.

In theory and practice, redox processes, which are among the most common chemical reactions, are of great importance. Breathing, fermentation and many biological processes in themselves are redox reactions. Redox reactions, accompanied by the movement of electrons, are a combination of two opposite processes of oxidation and reduction. Oxidation is impossible without simultaneous reduction and, conversely, the reduction of one substance is impossible without oxidation of another at the same time. The vast majority of reactions go through a series of stages, in which short-lived intermediate products play almost the main role. The course of the reaction and its direction depend on a number of conditions, namely: the $\mathrm{pH}$ of the medium, the concentration of the substances taking part in it, the temperature, the addition of additives that interfere with the progress of the reaction, etc. [5, 14].

Redox potential is calculated from the potential difference between an immersed electrode with an indifferent metal and a standard hydrogen electrode. It is set in volts (EB) or through the negative decimal logarithm of the partial pressure of molecular hydrogen $r H$. The indicator $r H$ gives an idea of the total redox state [11]. The results of determining the reduction energy and redox potential of the samples under study are shown in Fig. 7, 8.

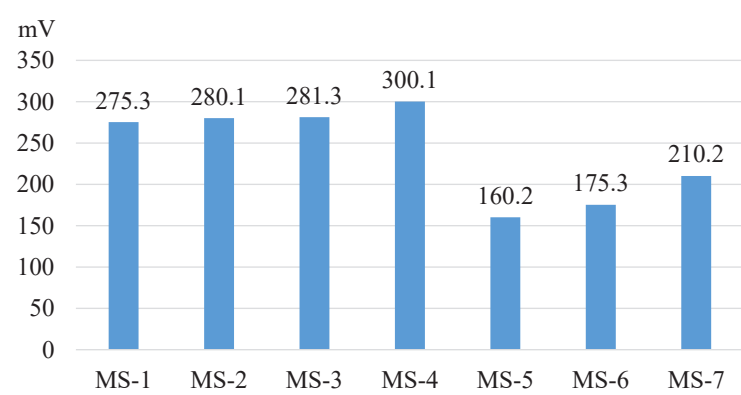

Fig. 7. Redox potential of the test samples

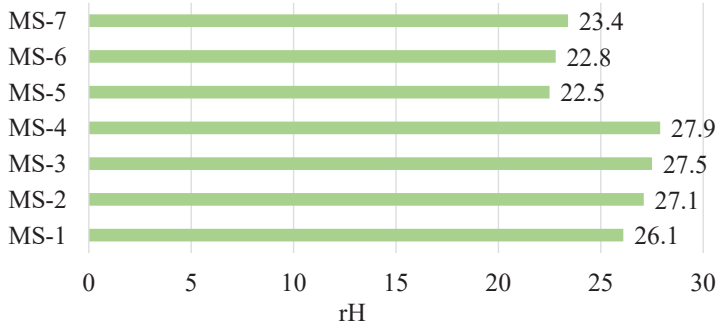

Fig. 8. Determination of the reduction energy of the test samples

From the diagrams presented, it can be seen that the samples with physalis puree have a lower redox potential relative to the control, which proves the positive effect of the physalis content in the samples on the predicted shelf life of sweet dishes.

The studies carried out have shown that the reduction energy of the samples under study is at a rather high level. This refers this group of dishes to products with an increased risk of microbiological contamination, therefore, maximum attention should be paid to the storage conditions of products. It can also be concluded that the samples with the addition of physalis puree are more stable to storage than the control and samples with banana puree.

In the laboratory conditions of the Department of Restaurant and Ayurvedic Products of the National University of Food Technologies (Kyiv, Ukraine), samples of sambuk with mashed banana and physalis were prepared, they were evaluated by a tasting commission, which included masters of the TR-1-1 M group and teachers of the department. The products were evaluated on a ten-point scale. The search for the optimal value and influence of puree of vegetable raw materials on the food system was solved as finding the extremum of the target multicriteria function of the product quality of a nonlinear nature with a system of restrictions on some quality indicators $[6,7,12]$. Based on the results of the tasting, an assessment of the organoleptic properties 
of finished products was obtained, which were used to determine the complex quality indicator using the «Quality polygon» method.

When evaluating the organoleptic characteristics of desserts, the critical limit for descriptors was set at 6.0 points. The value of research indicators that were below 4.0 (do not meet the requirements of regulatory documents and are not of scientific interest) were not taken into account.

To determine each quality indicator, the ranking method was used [8, 13, 15], the essence of which is that the least significant indicator is assigned rank 6 (critical limit), and the most important -10 . This number of experts ensures sufficient accuracy of estimates. Organoleptic analysis provides an opportunity to quickly and easily assess the quality of semi-finished products and finished products. Based on the data obtained from the organoleptic evaluation of sambuk samples, the quality criteria were calculated (based on the area of profilograms, which determines the overall comprehensive evaluation of new desserts [15]), which are shown in Fig. 9.

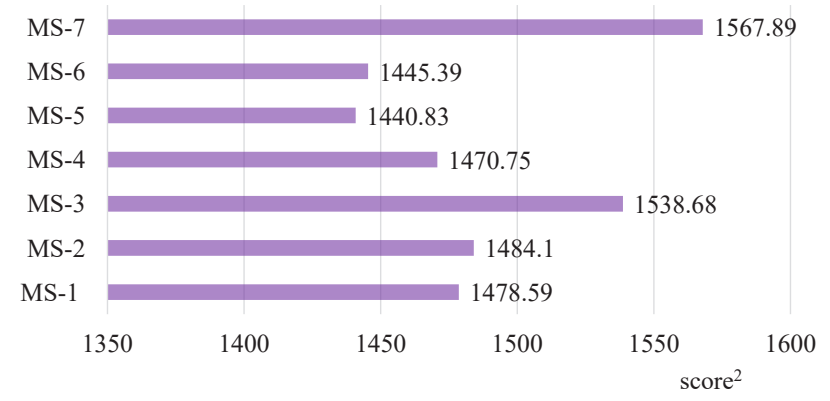

Fig. 9. The value of the quality criterion of samples

Analyzing all the investigated properties of model samples of sambuk, the best organoleptic and physicochemical indicators are found in sambuk desserts with the addition of banana puree in the amount of $35 \%$, and physalis puree in the amount of $38.5 \%$. In further research, it is necessary to provide for technological measures to improve the structure of the dessert and determine the term for the realization of the dish.

\section{Conclusions}

In the process of analyzing the technology of baked desserts, the prospect of improving apple sambuk with nontraditional plant raw materials was discovered. In the course of the study, the main indicators of the quality of sambuk were determined, which are essential for their use in finding the optimal dosage of banana and physalis puree. According to studies of the process of foaming of prototypes, it was found that puree of fruit raw materials, banana and physalis, exhibits stabilizing properties. The stability coefficient value is 2 times higher than the control when banana puree is added. In the case of giving physalis puree, this indicator exceeds the control by 1.45 times. Adding raw fruit puree significantly increases the specific foam volume (in samples with banana puree at $285.7 \mathrm{~cm}^{3} / \mathrm{g}$, and in samples with physalis puree at $221.2 \mathrm{~cm}^{3} / \mathrm{g}$ ). Organoleptic and physicochemical studies carried out show that for apple sambuk, the optimal dosage is $38.5 \%$ physalis puree and $35 \%$ banana puree.

The research results will be useful when introducing the production of apple sambuk with the addition of physalis puree and banana puree in restaurants.

\section{References}

1. Doublier, J. L., Launay, B., Guvelier, G. (1992). Viscoelastic Propertieso ffo Foods. Viscoelastic Properties of Foods. Barking, Essex: Elsevier, 371-434.

2. Stepanova, T. M. (2015). Innovative ideas in technology gelled sweet dishes based on fruit and berries raw materials. Bulletin of the National Technical University «KhPI» Series: New Solutions in Modern Technologies, 1 (39), 108-114.

3. Kalinowska, M., Bielawska, A., Lewandowska-Siwkiewicz, H., Priebe, W., Lewandowski, W. (2014). Apples: Content of phenolic compounds vs. variety, part of apple and cultivation model, extraction of phenolic compounds, biological properties. Plant Physiology and Biochemistry, 84, 169-188. doi: http:// doi.org/10.1016/j.plaphy.2014.09.006

4. Koretska, I., Deinychenko, L., Kravchenko, T. (2020). Analysis of the nonlinear criteria use for the foods quality assessment. Tourism of the XXI century: Clobal challenges and civilization values. Kyiv: KNUTE, 497-503. doi: http://doi.org/10.31617/ k.knute.2020-06-01.71

5. Dorokhovych, A. M., Kovbasa, V. M. (Ed.) (2015). Tekhnolohiia ta laboratornyi praktykum kondyterskykh vyrobiv $i$ kharchooykh kontsentrativ. Kyiv: Firma «INKOS», 632

6. Pushka, O. S. (2014). Vykorystannia strukturoutvoriuvachiv u desertakh pinnoi struktury. Novitni tendentsii u kharchovykh tekhnolohiiakh ta yakist i bezpechnist produktiv. Lviv: Liha pres, 31-34.

7. Katere, V. M., Matison, V. A., Fomenko, M. L. et. al. (2002). Organolepticheskiy analiz pischevykh produktov. Moscow: MGUPP, $16-72$.

8. Kuzmin, O. V., Ilchuk, N. V., Saltan, B. A., Sasnyk, S. S. (2018). Qualitative assessment of diets. Internauka, 1 (11 (51)), 69-76.

9. Foegeding, E. A., Luck, P. J., Davis, J. P. (2006). Factors determining the physical properties of protein foams. Food Hydrocolloids, 20 (2-3), 284-292. doi: http://doi.org/10.1016/ j.foodhyd.2005.03.014

10. Kitson, J. A., Ruck, J. A., Moyls, A. W. (1968). Utilizing an Expanding Western Apple Crop. Canadian Institute of Food Technology Journal, 1 (4), A94-A96. doi: http://doi.org/10.1016/ s0008-3860(68)74497-4

11. Kuzmin, O., Pozdniakov, S., Kiiko, V., Akimova, L. (2018). Development of quality management systems in the hotelrestaurant business. Transformational processes the development of economic systems in conditions of globalization: scientific bases, mechanisms, prospects. Riga: «Landmark» SIA, 1, 221-232.

12. Svidlo, K. V., Lypovyi, D. V. (2013). Tekhnolohiia zbyvanykh desertnykh strav herodiietychnoho pryznachennia. Naukovi pratsi Odeskoi natsionalnoi akademii kharchovykh tekhnolohii, 44 (2), 114-117.

13. Polyovyk, V., Koretska, I., Kuzmin, O., Zinchenko, T. (2020). Modeling of Innovative Technology of Fruit and Berry Desserts. Restaurant and Hotel Consulting. Innovations, 3 (2), 221-236. doi: http://doi.org/10.31866/2616-7468.3.2.2020.219706

14. Davis, J. P., Foegeding, E. A. (2007). Comparisons of the foaming and interfacial properties of whey protein isolate and egg white proteins. Colloids and Surfaces B: Biointerfaces, 54 (2), 200-210. doi: http://doi.org/10.1016/j.colsurfb.2006.10.017

15. Koretska, I. L., Zinchenko, T. V. (2017). Rekomendatsii shchodo vykorystannia profilohram dlia otsiniuvannia yakosti vyrobu. Available at: http://dspace.nuft.edu.ua/jspui/bitstream/123456789/ 27948/1/Zinchenko.pdf

Anastasia Vorobyova, Department of Technology of Restaurant and Ayurvedic Products, National University of Food Technologies, Kyiv, Ukraine, ORCID: https://orcid.org/0000-0002-7596-9399

Volodymyr Polyozyk, Assistant, Department of Technology of Restaurant and Ayurvedic Products, National University of Food Technologies, Kyiv, Ukraine, ORCID: https://orcid.org/0000-0001-8760-3813

$\triangle$ Iryna Koretska, PhD, Associate Professor, Department of Technology of Restaurant and Ayurvedic Products, National University of Food Technologies, Kyiv, Ukraine, e-mail: tac16@ukr.net, ORCID: https:// orcid.org/0000-0001-5680-5789

$\bowtie$ Corresponding author 